
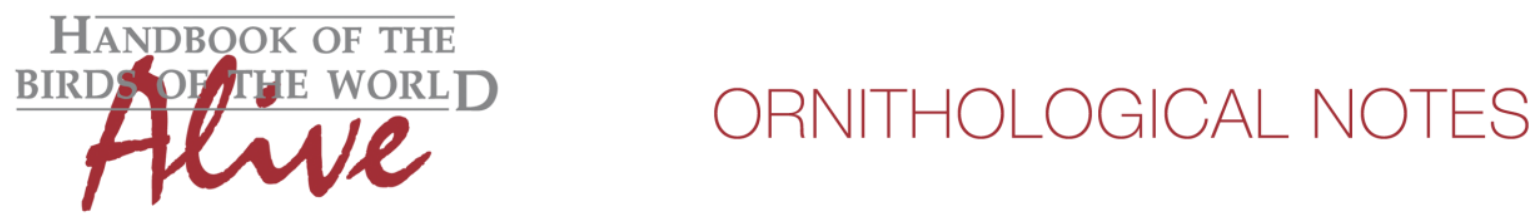

\title{
Notes on the vocalizations of Variable Pitohui (Pitohui kirhocephalus)
}

Peter Boesman

In the following we briefly analyze and compare voice of the different races of Variable Pitohui (Pitohui kirhocephalus). We also try to quantify the extent of any vocal differences using the criteria proposed by Tobias et al. (2010), as a support for taxonomic review.

We have made use of sound recordings available on-line from Xeno Canto (XC) and Macaulay Library (ML).

Pratt \& Beehler (2015) treat this group as three distinct species (with jobiensis included in Northern Variable Pitohui), but don't mention any differences in voice. I therefore compare the voice of the three groups that have been defined (Fig. 1):

Northern Variable Pitohui (kirhocephalus and eleven other taxa) (no recordings of jobiensis). $(n=11)$

$\begin{array}{ll}\text { max. freq. } & 2800-3750 \mathrm{~Hz} \\ \text { min. freq. } & 730-1100 \mathrm{~Hz} \\ \text { max. note length } & 0.18-0.56 \mathrm{~s} \\ \text { freq. range } & 1800-3050 \mathrm{~Hz} \\ \text { \# different notes } & 3-15\end{array}$

Southern Variable Pitohui (five taxa)

$\begin{array}{ll}\text { ( } n=8) & \\ \text { max. freq. } & 2200-3500 \mathrm{~Hz} \\ \text { min. freq. } & 600-900 \mathrm{~Hz} \\ \text { max. note length } & 0.19-0.58 \mathrm{~s} \\ \text { freq. range } & 1600-2700 \mathrm{~Hz} \\ \text { \# different notes } & 7-15\end{array}$

Raja Ampat Pitohui (cerviniventris, pallidus)

$(n=3)$

max. freq. $\quad 4090-4470 \mathrm{~Hz}$

$\min$. freq. $\quad 1130-1400 \mathrm{~Hz}$

max. note length $\quad 0.20-0.28 \mathrm{~s}$

freq. range $2690-3340 \mathrm{~Hz}$

\# different notes $5-7$

Northern Variable Pitohui seems to have two fairly distinctive song patterns: either a very simple repetition (in duet?) of several short upslurred or downslurred notes (which has not been seen in samples of the other 2 groups), or a complex phrase of several different melodious whistles. These whistles can be quite complex modulated, which is seemingly less the case in the other 2 groups.

Southern Variable Pitohui apparently reaches the lowest frequencies. Raja Ampat Pitohui clearly reaches higher frequencies, and song is possibly somewhat less varied, delivered more leisurely, with less different notes. 

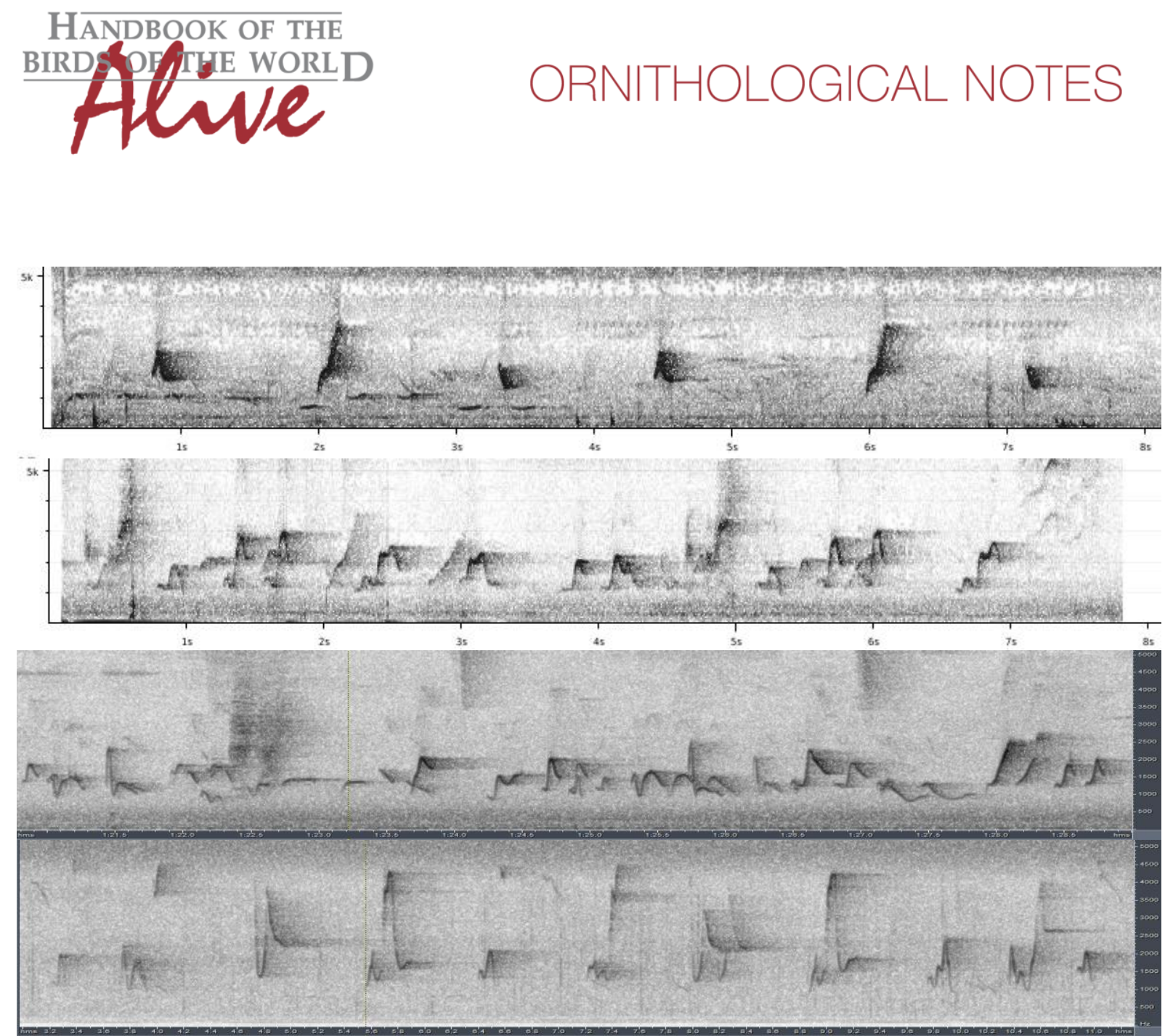

Figure 1: from top to bottom: simple and more complex song of northern group (two), song of southern group and Raja Ampat Pitohui.

All in all, taking into account the degree of variation, and with some reservation because of the rather low number of available recordings, there seems to be indeed some difference in voice among the 3 groups:

- Southern (vs Northern) reaches slightly lower frequencies (1) and may have a more simple repertoire (0-1). Total vocal score 1-2

- Southern (vs Raja Ampat) vocalizes at significantly lower frequencies (max, $\min$ ) and within a smaller frequency range (score at least 2-3).

- Northern (vs Raja Ampat) vocalizes at lower frequencies (2) within a narrower frequency range, and seemingly has a more complex repertoire (0-1). Total score 2-3.

The 'Raja Ampat Pitohui' group thus seems to show vocally the largest differences.

This note was finalized on 8th October 2015, using sound recordings available on-line at that moment. We would like to thank in particular the sound recordists who placed their recordings for this species on XC and ML: Patrik Aberg, Mack Andrew, Bruce Beehler, Mike Catsis, Phil Gregory, John V Moore, Niels Poul Dreyer, Thane Pratt Andrew Spencer and Bas Van Balen. 


\section{References}

Pratt, T.K., Beehler, B.M. (2015). Birds of New Guinea (second edition). Princeton University Press. Princeton and Oxford.

Tobias, J.A., Seddon, N., Spottiswoode, C.N., Pilgrim, J.D., Fishpool, L.D.C. \& Collar, N.J. (2010). Quantitative criteria for species delimitation. Ibis 152(4): 724-746.

\section{Recommended citation}

Boesman, P. (2016). Notes on the vocalizations of Variable Pitohui (Pitohui kirhocephalus). HBW Alive Ornithological Note 158. In: Handbook of the Birds of the World Alive. Lynx Edicions, Barcelona. (retrieved from http://www.hbw.com/node/932088 on 18 August 2016). 